\title{
PERBEDAAN KEMAMPUAN PEMECAHAN MASALAH MATEMATIKA SISWA MELALUI MODEL PEMBELAJARAN KOOPERATIF TIPE NUMBERED HEAD TOGETHER DAN STUDENT TEAMS ACHIEVEMENT DIVISION DI MTs AL-AZHAR BULU CINA
}

\author{
Lilis Saputri \\ Falinsyah16@gmail.com
}

\begin{abstract}
ABSTRAK
Penelitian ini bertujuan untuk mengetahui perbedaan kemampuan pemecahan masalah matematika siswa yang diberikan model pembelajaran numbered head together dan student teams achievement division. Penelitian ini dilakukan di MTs Al-Azhar Bulu Cina. Jenis penelitian dilakukan menggunakan quasi eksperimen, sampel yang digunakan random sampling untuk menentukan kelas eksperimen dan kelas kontrol dari 3 kelas. Desain penelitian ini adalah two-group (pre-test - posttest). Instrument yang digunakan adalah tes kemampuan pemecahan masalah matematika siswa. Nilai kemampuan pemecahan masalah matematika siswa kelas eksperimen (rata-rata 67,30, simpangan baku 11,05 varians 122) dan kelas kontrol (rata-rata 55,93, simpangan baku 11,9 varians 141), berdasarkan uji-t diperoleh $t_{\text {hitung }} 3,140$ dan $t_{\text {tabel }}$ pada taraf signifikansi 0,05 sebesar 1,6698 atau $t_{\text {hitung }}>t_{\text {tabel. }}$ Sehingga diperoleh $\mathrm{H}_{0}$ ditolak dan $\mathrm{H}_{\mathrm{a}}$ diterima, maka terdapat perbedaan kemampuan pemecahan masalah matematika siswa yang diberikan model pembelajaran numbered head together dan model pembelajaran student teams achievement division.
\end{abstract}

Kata Kunci : Kemampuan Pemecahan Masalah Matematika, Model Pembelajaran Kooperatif Tipe Numbered Head Together dan Student Teams Achievement Division 


\section{PENDAHULUAN}

Matematika merupakan salah satu ilmu dasar yang sangat dibutuhkan dalam perkembangan ilmu pengetahuan dan teknologi. Tujuan pembelajaran matematika menurut Yulanda, dkk (2014) adalah agar siswa memiliki kemampuan sebagai berikut : “(1) Memahami konsep matematika, menjelaskan kriteria antar konsep dan mengaplikasikan konsep atau alogaritma, secara luwes, akurat, efesien dan tepat dalam pemecahan masalah, (2) Menggunakan penalaran pada pola dan sifat, melakukan manipulasi matematika dalam membuat generalisasi, menyusun bukti, atau menjelaskan gagasan dan pernyataan matematika, (3) Memecahkan masalah yang meliputi kemampuan memahami masalah, merancang model matematika, menyelesaikan model dan menafsirkan solusi yang diperoleh, (4) Mengomunikasikan gagasan dengan simbol, tabel, diagram, atau media lain untuk memperjelas keadaan atau masalah, (5) Memiliki sikap menghargai kegunaan matematika dalam kehidupan, yaitu memiliki rasa ingin tahu, perhatian, dan minat dalam matematika, serta sikap ulet dan percaya diri dalam pemecahan masalah".

Tujuan pembelajaran matematika menurut kurikulum adalah mengembangkan kemampuan memecahkan masalah. Pembelajaran pemecahan masalah merupakan salah satu alternatif pembelajaran yang dipandang dapat mendukung tercapainya tujuan pembelajaran matematika. Menurut Suryadi (dalam Kariasa, dkk, 2014) bahwa "pemecahan masalah merupakan aktivitas dan tujuan yang penting dalam pembelajaran matematika, akan tetapi pemecahan masalah masih dianggap sebagai tugas yang sulit". Pemecahan masalah masih dianggap sebagai tugas paling sulit bagi siswa untuk mempelajarinya dan bagi guru untuk mengajarkannya. Banyak faktor yang menyebabkan rendahnya kemampuan siswa dalam pemecahan masalah. Oleh sebab itu peneliti melakukan sebuah tes awal kepada siswa mengenai kemampuan pemecahan masalah :

1. Beda dua bilangan adalah 12 dan 3 kali bilangan yang lebih besar sama dengan 9 kali bilangan yang lebih kecil. Tentukan kedua bilangan itu.

2. Sebuah bioskop mampu menjual karcis kelas I dan kelas II sebanyak 650 lembar. Harga setiap karcis untuk kelas I adalah Rp. 10.000,00 dan harga setiap karcis kelas II adalah Rp. 7.500,00. Jika hasil penjualan seluruh karcis adalah Rp. 5.500.000,00, tentukan banyak karcis kelas I dan kelas II yang terjual.

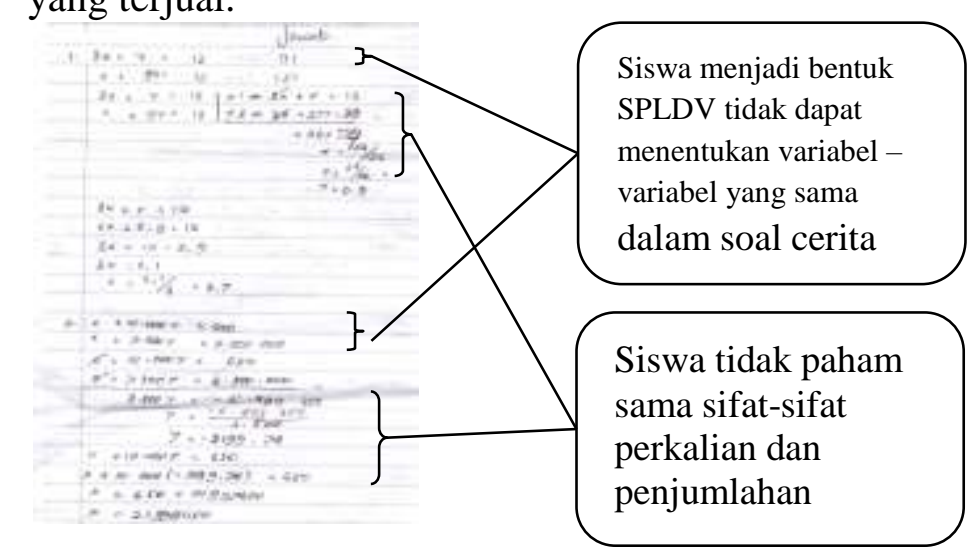

\section{Gambar 1.1 jawaban siswa}

Dari analisis tes yang dilakukan oleh peneliti, peneliti menemukan rendahnya kemampuan pemecahan masalah tersebut disebabkan oleh kesempatan siswa/siswi untuk menemukan dan membangun pengetahuannya sendiri tidak ada, kegiatan belajar berpusat pada guru (teacher centered) atau hanya satu arah saja, guru masih mengemukakan model pembelajaran yang konvesional sehingga suasana pembelajaran berlangsung. Guru lebih fokus untuk menyelesaikan tuntutan kurikulum pembelajaran matematika dan cendrung kurang 
efektif dalam mengadakan refleksi terhadap proses belajar siswa.

Saputri (2018) untuk "mencapai kemampuan pemecahan masalah siswa/siswi dalam matematika bukanlah satu hal yang mudah karena masalah suatu matematika dilakukan secara individual". Setiap siswa/siswi mempunyai kemampuan yang berbeda dalam memecahkan masalah matematika. Namun demikian peningkatan kemampuan pemecahan masalah matematika perlu diupayakan demi keberhasilan siswa/siswi dalam belajar. Salah satu untuk mengatasi permasalahan tersebut, guru dituntut untuk profesional dalam merencanakan dan melaksanakan pembelajaran. Oleh karena itu, guru harus mampu mendesain pembelajaran matematika dengan metode, teori atau pendekatan yang mampu menjadikan siswa/siswi sebagai subjek belajar bukan lagi objek belajar.

Kemampuan pemecahan masalah matematika dapat dilihat dari Kenney (dalam Saputri, 2018) menyarankan ada empat langkah proses pemecahan masalah matematika yaitu: “(1) memahami masalah, (2) merencanakan pemecahan masalah, (3) melaksanakan pemecahan masalah, dan (4) memeriksa kembali hasil pemecahan masalah. Gambaran di atas menunjukkan bahwa kemampuan pemecahan masalah dalam matemtika merupakan hal yang memiliki peran strategis dalam pembentukan pola pikir siswa".

Penggunaan model pembelajaran kooperatif adalah salah satu alternatif lain untuk mencapai kemampuan pemecahan masalah siswa/siswi. Pembelajaran kooperatif merupakan strategi pembelajaran yang mendorong siswa/siswi aktif menemukan sendiri pengetahuan melalui keterampilan proses. Siswa/siswi belajar dalam kelompok kecil yang kemampuannya heterogen. Dalam menyelesaikan tugas kelompok setiap anggota saling berkerja sama dan saling membantu dalam memahami suatu materi.

Materi yang sesuai disajikan dengan model pembelajaran kooperatif adalah materimateri yang menuntut pemahaman tinggi terhadap nilai, konsep, atau prinsip, serta masalah-masalah aktual yang terjadi di masyarakat. Untuk mengetahui masalahmasalah dalam kehidupan nyata juga dapat diberikan. Salah satu upaya untuk meningkatkan kemampuan pemecahan masalah dengan menerapkan model pembelajaran kooperatif tipe numbered head together dan students teams achievement division.

Numbered head together adalah suatu metode belajar di mana setiap siswa/siswi diberi nomor kemudian dibuat suatu kelompok kemudian secara acak guru memanggil nomor dari siswa/siswi. Trianto (dalam Istiningrum, dkk 2012) mengemukakan bahwa "numbered head together atau penomoran berpikir bersama adalah jenis pembelajaran kooperatif yang dirancang untuk mempengaruhi pola interaksi siswa dan sebagai alternatif terhadap struktur kelas tradisional".

Pada pembelajaran kooperatif siswa/siswi percaya bahwa keberhasilan mereka akan tercapai jika setiap anggota kelompok berhasil. Dalam kegiatan belajar yang di sekolah selama ini, sebenarnya sudah menerapkan belajar kelompok. Tujuan kerja kelompok adalah agar siswa/siswi mampu bekerjasama dengan teman yang lain dalam mencapai tujuan bersama. Keberhasilan kerja kelompok ini menuntut kegiatan yang kooperatif dari beberapa individu tersebut. Pembelajaran kooperatif tipe numbered head together merupakan salah satu tipe pembelajaran kooperatif yang menekankan pada struktur khusus yang dirancang untuk mempengaruhi pola interaksi siswa dan memiliki tujuan untuk meningkatkan penguasaan akademik. Tipe ini dikembangkan oleh Spenser Kagan (dalam Hartati, 2015) 
dengan "melibatkan para siswa dalam menelaah bahan yang tercakup dalam suatu pembelajaran dan mengecek pemahaman mereka terhadap isi pembelajaran tersebut".

Model numbered head together merupakan tipe pembelajaran kooperatif yang terdiri ada empat tahap yang digunakan untuk meriview fakta-fakta dan informasi dasar yang berfungsi untuk mengatur interaksi siswa/siswi. Siregar (dalam Wakhyudin, 2014) mengungkapkan langkah-langkah model numbered head together dari adalah sebagai berikut : (a) langkah 1: penomoran (Numbereding), guru membagi para siswa menjadi beberapa kelompok yang beranggotakan tiga sampai lima orang sehingga tiap siswa dalam kelompok kepada para siswa. (b) langkah 2: pengajuan pertanyaan (Questioning), guru mengajukan pertanyaan kepada para siswa. (c) langkah 3: berpikir bersama (Head Together), para siswa berpikir bersama untuk menggambarkan dan meyakinkan bahwa tiap orang mengetahui jawaban tersebut. (d) langkah 4: pemberian jawaban (Answering), guru menyebut satu nomor dan para siswa tiap kelompok dengan nomor yang sama mengangkat tangan dan menyiapkan jawaban untuk seluruh kelas.

Model pembelajaran ini juga dapat digunakan untuk memecahkan masalah yang tingkat kesulitannya terbatas, menurut Muhammad Nur (dalam Siswanto, dkk, 2011) "keterlibatan total semua siswa yang merupakan upaya yang sangat baik untuk meningkatkan tanggung jawab individual dalam diskusi kelompok. Selain itu model pembelajaran numbered head together memberi kesempatan kepada siswa untuk membagi ide-ide dan mempertimbangkan jawaban yang paling tepat".

Model dan pendekatan pembelajaran merupakan bagian dari faktor eksternal yang mempengaruhi kelancaran proses pembelajaran matematika. Dalam pembelajaran matematika banyak model dan pendekatan yang dapat digunakan oleh guru agar dapat mempermudah ataupun menghambat pencapaian tujuan pembelajaran. Pemilihan model dan pendekatan pembelajaran matematika yang tepat mengakibatkan pemahaman siswa/siswi terhadap konsep yang disampaikan akan baik sehingga berdampak positif terhadap prestasi belajar matematika siswa/siswi. Haydon, et al (dalam Dewi, A.P., dkk 2014) "model pembelajaran kooperatif numbered head together lebih efektif meningkatkan aktivitas yang relevan dengan pembelajaran dan memberikan pengaruh terhadap peningkatkan prestasi belajar siswa".

Suprapto (dalam Saputri, 2017) mengemukakan "student teams achievement division merupakan model pembelajaran kooperatif yang berlandasankan pada pendekatan konstruktivisme dimana siswa belajar dan bekerja dalam kelompok-kelompok kecil serta kolaboratif yang anggotanya terdiri dari 4 hingga 6 orang dengan struktur kelompok yang bersifat heterogen". Dalam student teams achievement division guru menyampaikan materi pelajaran matematika dan setiap kelompok harus menguasai materi pelajaran tersebut, setelah itu siswa/siswi mengikuti kuis yang bersifat individu dan pada saat kuis mereka tidak diperkenankan membantu satu sama lain. Pembelajaran kooperatif memiliki beberapa model yang telah dikembangkan oleh para ahli, "model pembelajaran kooperatif tipe student teams achievement division berintikan kegiatan menyampaikan suatu materi oleh guru, kemudian peserta didik bergabung dalam kelompok yang terdiri atas empat atau lima orang untuk menyelesaikan soal-soal yang diberikan oleh guru" (Tim MKPBM dalam Muharom, 2014). Pada proses pembelajaran kooperatif tipe student teams achievement 
division melalui tahapan-tahapan sebagai berikut : “(1) Guru membentuk kelompok yang anggotanya 4-5 orang secara heterogen. (2) Guru menyajikan pelajaran. (3) Guru memberi tugas untuk pada kelompok untuk diberikan oleh anggota-anggota kelompok. (4) Peserta didik yang bisa mengerjakan tugas/soal menjelaskan kepada anggota kelompok lainnya sehingga semua anggota dalam kelompok itu mengerti. (5) Guru memberi kuis/pertanyaan kepada seluruh siswa. Pada saat menjawab kuis/pertanyaan siswa tidak boleh saling membantu. (6) Guru memberi penghargaan (rewards) kepada kelompok yang memiliki nilai/poin tinggi. (7) Guru memberikan evaluasi. (8) Penutup".

Berdasarkan uraian latar belakang masalah diatas rumusan masalah dari penelitian ini yaitu : Apakah terdapat perbedaan kemampuan pemecahan masalah matematika siswa melalui model pembelajaran kooperatif tipe numbered head together danmodel pembelajaran kooperatif tipe student teams achievement division di kelas VIII MTs AL AZHAR Bulu Cina?

\section{METODOLOGI PENELITIAN}

Penelitian ini merupakan penelitian quasi eksperimen (eksperimen semu) yang dilakukan dilakukan di MTs Al-Azhar Bulu Cina. Terdapat dua kelompok sampel pada penelitian ini yaitu kelompok eksperimen 1 yang mendapatkan pembelajaran matematika dengan menggunakan model pembelajaran kooperatif tipe numbered head togethe dan kelompok eksperimen 2 melakukan pembelajaran dengan menggunakan model pembelajaran kooperatif tipe student teams achievement division. Populasi dari penelitian ini adalah seluruh siswa kelas VIII MTs Al-Azhar Bulu Cina yang terdiri dari tiga kelas. Pada penelitian ini pengambilan sampel menggunakan teknik simple random sampling dimana kelas VIII ${ }^{1}$ yang berjumlah 43 siswa sebagai kelas eksperimen 1 dan kelas VIII $^{3}$ yang berjumlah 31 siswa sebagai kelas eksperimen 2. Dengan demikian sampel keseluruhan berjumlah 74 siswa. Desain penelitian yang digunakan adalah desain Pretest-Posttest Control Group Design.

$\begin{array}{cccc}\text { Kelas } & \text { Pretest } & \text { Perlakuan } & \text { Posttest } \\ \text { Eks 1 } & \mathrm{T}_{1} & \mathrm{X}_{1} & \mathrm{~T}_{2} \\ \text { Eks 2 } & \mathrm{T}_{1} & \mathrm{X}_{2} & \mathrm{~T}_{2}\end{array}$

Sumber: (Suprapto, 2015)

Kedua kelompok diberikan pre-test dan post-test dengan menggunakan instrumen tes kemampuan pemecahan masalah matematika yang berbentuk tes uraian sebanyak 5 soal. Langkah awal yang dilakukan peneliti dalam menyusun tes adalah membuat kisi-kisi soal kemudian dilanjutkan menyusun soal dan alternatif jawaban serta menentukan skor untuk setiap butir soal. Sebelum digunakan, instrumen tes terlebih dahulu divalidasi oleh para validator untuk selanjutnya di uji cobakan untuk diuji validitas, reliabilitas, taraf kesukaran, dan daya pembeda. Uji coba dilakukan pada siswa kelas IX MTs AlWasliyah 48 Binjai.

Untuk menguji hipotesis digunakan uji-t. Uji-t ini digunakan untuk mengetahui adanya perbedaan kemampuan pemecahan masalah matematika siswa yang diajarkan dengan menggunakan pembelajaran model kooperatif tipe numbered head together dan siswa yang diajarkan dengan model kooperatif tipe student teams achievement division.

\section{HASIL DAN PEMBAHASAN PENELITIAN}

Berdasarkan penelitian yang telah dilakukan, diperoleh data kemampuan pemecahan masalah matematika pada kelas eksperimen 1 diperoleh nilai terendahnya 11 , 
nilai tertinggi 46 dan untuk kelas eksperimen 2 diperoleh nilai terendah 0 , nilai tertinggi 40 . Untuk lebih jelasnya, data hasil tes kemampuan pemecahan masalah matematika siswa kelas eksperimen 1 dan kelas eksperimen 2 disajikan dalam tabel berikut ini:.

Tabel 1. Data Pretest Kelas Eksperimen 1 Dan Kelas Ekperimen 2

\begin{tabular}{|c|c|c|c|}
\hline No. & Statistika & $\begin{array}{c}\text { Kelas } \\
\text { Eksperimen } \\
1\end{array}$ & $\begin{array}{c}\text { Kelas } \\
\text { Ekperimen } \\
2\end{array}$ \\
\hline 1 & $\mathrm{~N}$ & 43 & 31 \\
\hline 2 & $\begin{array}{c}\text { Jumlah } \\
\text { Nilai }\end{array}$ & 991 & 698 \\
\hline 3 & Rata-rata & 23,04 & 22,5 \\
\hline 4 & $\begin{array}{l}\text { Standar } \\
\text { Deviasi }\end{array}$ & 75 & 124 \\
\hline 5 & $\begin{array}{c}\text { Simpangan } \\
\text { Baku }\end{array}$ & 8,7 & 11,1 \\
\hline 6 & Maksimum & 46 & 40 \\
\hline 7 & Minimum & 11 & 0 \\
\hline
\end{tabular}

perhitungan pretest pada kelas eksperimen 1 diperoleh nilai standar deviasi 75 simpangan baku 8,7. Sedangkan pada kelas eksperimen 2 diperoleh nilai standar deviasi 124 dan simpangan bakunya yaitu 11,1. Hasil pemberian pretest diperoleh nilai rata-rata dikelas eksperimen 1 adalah 23,04 dan hasil pemberian nilai pretest pada kelas eksperimen 2 diperoleh nilai rata-rata 22,5. Secara visual penyebaran data kemampuan pemecahan masalah matematika siswa kelas eksperimen 1 yang menggunakan model pembelajaran kooperatif tipe numbered head together dan kelas eksperimen 2 yang menggunakan model pembelajaran kooperatif tipestudent teams achievement division dapat dilihat pada histogram terdapat perbedaan pada nilai ratarata, simpangan baku, dan standar deviasi pretest kelas eksperimen 1 dan kelas eksperimen 2 sebagai berikut :

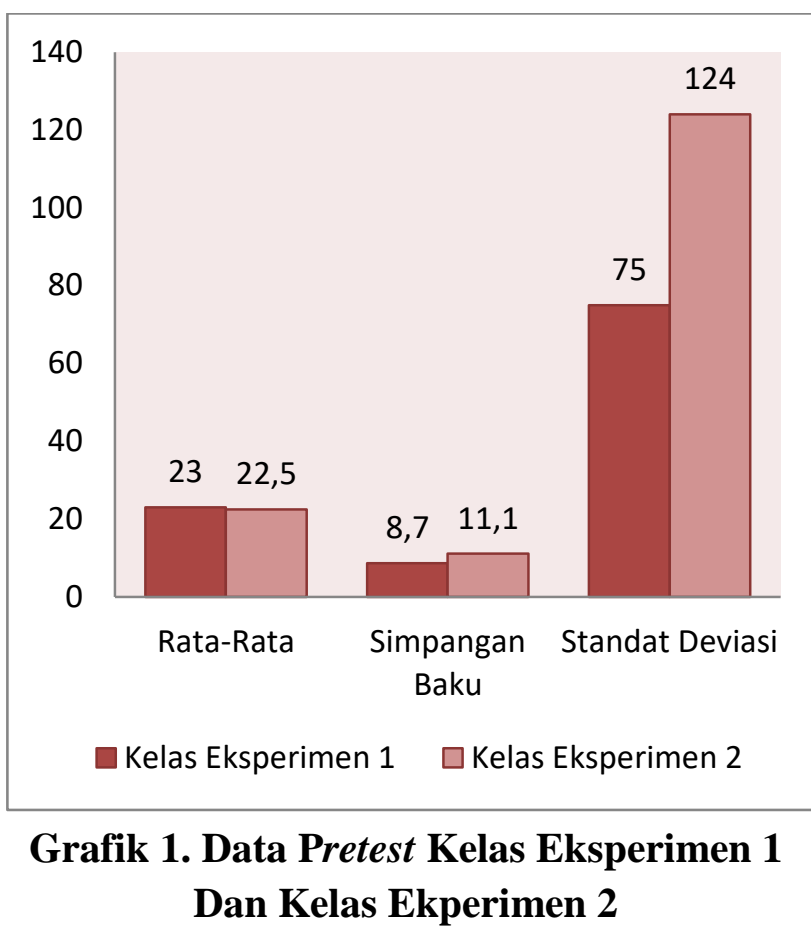

Hasil diatas menunjukkan bahwa perhitungan rata-rata, simpangan baku dan standar deviasi pada pretest menunjukkan adanya perbedaan pada kelas eksperimen 1 yang menggunakan model pembelajaran kooperatif tipe nmbered head together dan pada kelas eksperimen 2 yang menggunakan model pembelajaran kooperatif tipe student teams achievement division.

Setelah diberikan pretest pada kedua kelas menunjukkan kemampuan pemecahan masalah matematika awal siswa hampir sama, maka dilakukan pembelajaran yang berbeda yakni dikelas eksperimmen 1 dengan model pembelajaran kooperatif tipe numbered head together dan model pembelajaran kooperatif tipe student teams achievement division dikelas eksperimen 2. Di bawah ini menujukkan data posttest siswa kelas eksperimen 1 dan kelas eksperimen 2.

Tabel 2. Data Posttest Kelas Eksperimen 1 Dan Kelas Ekperimen 2

\begin{tabular}{|c|c|c|c|}
\hline No. & Statistika & $\begin{array}{c}\text { Kelas } \\
\text { Eksperimen }\end{array}$ & $\begin{array}{c}\text { Kelas } \\
\text { Kontrol }\end{array}$ \\
\hline 1 & $\mathrm{~N}$ & 43 & 31 \\
\hline 2 & Jumlah Nilai & 2894 & 1734 \\
\hline
\end{tabular}




\begin{tabular}{|c|c|c|c|}
\hline 3 & Rata-rata & 67,30 & 55,93 \\
\hline 4 & $\begin{array}{c}\text { Standar } \\
\text { Deviasi }\end{array}$ & 122 & 141 \\
\hline 5 & $\begin{array}{c}\text { Simpangan } \\
\text { Baku }\end{array}$ & 11,05 & 11,9 \\
\hline 6 & Maksimum & 83 & 78 \\
\hline 7 & Minimum & 40 & 37 \\
\hline
\end{tabular}

Pada tabel diatas terlihat bahwa banyak perhitungan posttest pada kelas eksperimen 1 diperoleh nilai standar deviasi 122 simpangan baku 11,05. Sedangkan pada kelas eksperimen 2 diperoleh nilai standar deviasi 141 dan simpangan bakunya yaitu 11,9. Hasil pemberian posttest diperoleh nilai rata-rata dikelas eksperimen 1 adalah 67,30 dan hasil pemberian nilai posttest pada kelas eksperimen 2 diperoleh nilai rata-rata 55,93. Secara visual penyebaran data kemampuan pemecahan masalah matematika siswa kelas eksperimen yang menggunakan model pembelajaran kooperatif tipe numbered head together dan Kelas kelas eksperimen 2 yang menggunakan model Eks 1 pembelajaran kooperatif tipe student teams 67,30 achievement division dapat dilihat pada histogram perbedaan nilai rata-rata, simpangan baku, dan standar deviasi posttest kelas eksperimen dan kelas kontrol sebagai berikut.

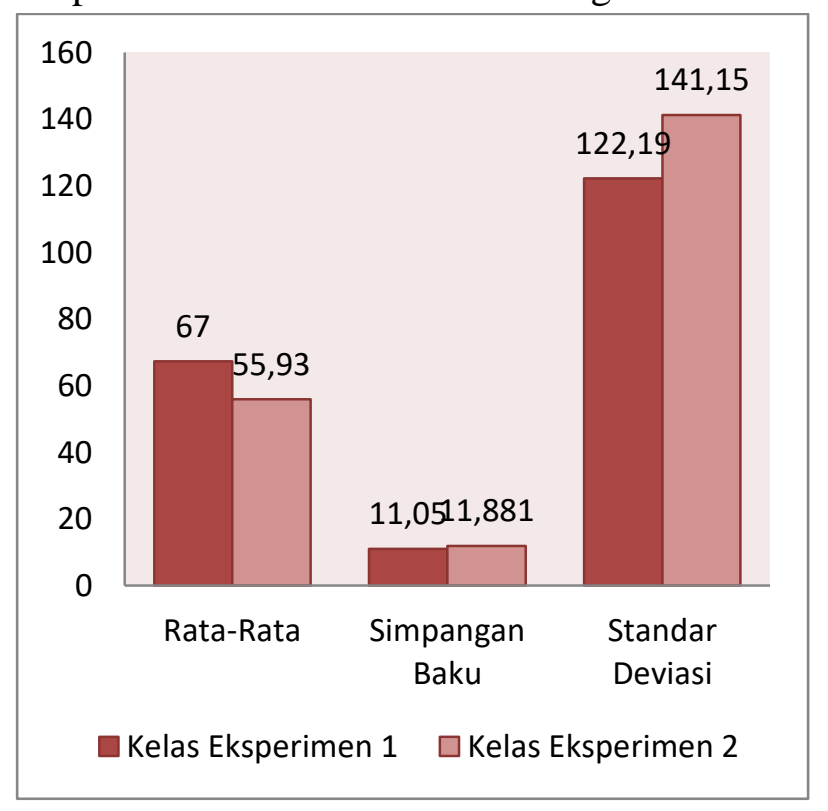

Garfik 2. Data Posttest Kelas Eksperimen 1 Dan Kelas Ekperimen 2

Hasil perhitungan rata-rata, simpangan baku dan standar deviasi posttest menunjukkan adanya perbedaan pada kelas eksperimen 1 yang menggunakan model pembelajaran kooperatif tipe numbered head together dan pada kelas eksperimen 2 yang menggunakan model pembelajaran pembelajaran kooperatif tipe student teams achievement division.

Untuk menganalisis uji hipotesis, peneliti menggunakan uji-t pada kemampuan pemecahan masalah matematika siswa yang diajarkan menggunakan model pembelajaran numbered head together dan model pembelajaran pembelajaran kooperatif tipe student teams achievement division.

Tabel 3. Hipotesis Penelitian

\begin{tabular}{|l|c|c|c|c|c|}
\hline \multicolumn{2}{|c|}{ Rata-rata Nilai } & $\mathbf{t}_{\text {hitung }}$ & $\mathbf{t}_{\text {tabel }}$ & $\begin{array}{c}\text { Selisih } \\
\text { Mean }\end{array}$ & $\begin{array}{c}\text { Kesimpu } \\
\text { lan }\end{array}$ \\
\hline $\begin{array}{l}\text { Kelas } \\
\text { Eks 1 }\end{array}$ & Kelas & & & & $\begin{array}{c}\mathrm{H}_{\mathrm{a}} \\
\text { Eks 2 } \\
67,30\end{array}$ \\
55,93 & 3,140 & 1,667 & 11,37 & $\begin{array}{c}\text { diterima } \\
\text { Ho } \\
\text { ditolak }\end{array}$ \\
\hline
\end{tabular}
menunjukkan adanya perbedaan pada kelas eksperimen 1 dan kelas eksperimen 2 . Berdasarkan perhitungan dengan menggunakan uji-t diperoleh hasil $t_{\text {hitung adalah 4,229 }}$ sedangkan nilai $t_{\text {tabel }}$ adalah 1,6698. Dengan demikian $t_{\text {hitung }}>\mathrm{t}_{\text {tabel }}$ ini berarti $\mathrm{H}_{0}$ ditolak dan $\mathrm{H}_{\mathrm{a}}$ diterima, dengan demikian dapat disimpulkan bahwa terdapat perbedaan kemampuan pemecahan masalah matematika siswa melalui model pembelajaran kooperatif tipe numbered head together danmodel pembelajaran kooperatif tipe student teams achievement division di kelas VIII MTs AL AZHAR Bulu Cina.

Selanjutnya selama penelitian pada kelas eksperimen 1 yang menggunakan pembelajaran kooperatif tipe numbered head together dalam menyelesaikan masalah terlihat siswa mampu 
menyelesaikan soal-soal yang ada pada tes kemampuan pemecahan masalah dan juga siswa mampu untuk menyimpulkan. Selain itu siswa dapat menentukan masalah, berdiskusi dengan siswa lainnya dengan saling tanya jawab dan bekerja sama. Sebaliknya, dalam kelas eksperimen 2 yang menggunakan model pembelajaran kooperatif tipe student teams achievement division menjadi siswa kurang aktif, siswa kurang mampu mengerjakan soalsoal yang diberikan. Sehingga dapat disimpulkan bahwa model numbered head together lebih baik dan sangat sesuai dengan kemampuan pemecahan masalah matematika siswa dibandingkan dengan model pembelajaran student teams achievement division.

\section{KESIMPULAN DAN SARAN}

Berdasarkan analisis data dan pembahasan maka dapat disimpulkan bahwa uji-t 3,140>1,6698 maka $\mathrm{H}_{0}$ ditolak dan $\mathrm{H}_{\mathrm{a}}$ diterima. Pada analisis posttest kelas eksperimen memperoleh nilai rata-rata 67,30, simpangan baku 11,05 dan standar deviasi 122, dan pada kelas kontrol memperoleh nilai ratarata 55,93, simpangan baku 11,9 dan standar deviasi 141. Sehingga dapat disimpulkan bahwa adanya perbedaan kemampuan pemecahan masalah matematika siswa Model pembelajaran kooperatif tipe numbered head together dan model pembelajaran kooperatif tipe student teams achievement division pada materi sistem persamaan linear dua variabel kelas VIII MTs Al-Azhar Bulu Cina Tahun Pelajaran 2016/2017.

Berdasarkan kesimpulan diatas dan pengalaman dalam proses belajar mengajar yang terjadi selama penelitian, maka penulis dapat memberikan saran-saran sebagai berikut: 1. Bagi Siswa a. Siswa hendaknya mengembangkan kegiatan belajar kelompok, guna meraih kemampuan pemecahan masalah matematika siswa.

b. Siswa hendaknya berlatih untuk bersikap kooperatif dan mau bekerja sama dengan guru maupun dengan siswa lain secara solid dan konstruktif guru meningkatkan kualitas kegiatan pembelajaran.

2. Bagi Guru

a. Guru hendaknya menerapkan model numbered head together guna mengembangkan kemampuan pemecahan masalah matematika siswa karena terbukti lebih optimal dibandingkan student teams achievement division dalam meningkatkan kemampuan pemecahan masalah matematika siswa.

b. Guru hendaknya lebih jeli dalam menerapkan kedua model tersebut terutama dalam dalam hal melakukan inovasi terhadap terhadap kuis individual yang merupakan salah satu saran penting guna mengasah daya pikir siswa dan berkontribusi pada pencapaian kemampuan pemecahan masalah matematika yang optimal.

c. Guru hendaknya senantiasa mengembangkan kemampuan manajemen kelasnya hingga dapat mengarahkan siswa untuk terlibat langsung dalam kegiatan pembelajaran dan saling kerja sama (bersikap kooperatif) baik pada guru maupunsiswa yang lain secara positif mengingat salah satu hal yang tersulit dari praktek pelaksanaan model pembelajaran kooperatif adalah adanya siswa-siswa yang tidak turut serta berkontribusi dalam kegiatan kelompok dan kegaduhan yang sangat mungkin muncul selama pembelajaran berlangsung. 
a. Sekolah hendaknya mampu memberikan dukungan kepada segenap warga, baik kepala sekolah, guru, siswa, maupun segenap karyawannya guna membentuk iklim belajar yang kondusif dan penuh inovasi.

b. Sekolah hendaknya mampun meningkatkan kelengkapan dan kualitas fasilitas pendukung kegiatan pembelajaran di setiap kelas.

4. Bagi penelitian selanjutnya, sebagai tambahan wawasan tentang penggunaan model numbered head together dalam menjalankan tugas pengajaran sebagai calon tenaga pengajar di masa depan.

5. Bagi pembaca, sebagai bahan informasi yang ingin melakukan penelitian sejenis.

Bagi lembaga pendidikan, sebagai informasi atau sumbangan pemikiran untuk meningkatkan kualitas pembelajaran yang berkaitan dengan pendekatan pembelajaran.

\section{DAFTAR PUSTAKA}

Dewi, A.P., Tri Atmojo Kusmayadi, dan Budi Usodo. Eksperimentasi Model Numbered Heads Together Dengan Make A Match (NHT MM) Dan Numbered Heads Together Dengan Bamboo Dancing (NHT BD) Ditinjau Dari Kecerdasan Interpersonal, Jurnal Elektronik Pembelajaran Matematika,No. 2, Vol. 2, 2014.

Hartati, Puji. Peningkatna Kemampuan Memecahkan Masalah Yang Berkaitan Dengan Bangun Ruang Sisu Lengkung Melalui Model Pembelajara NHT, Jurnal Penelitian Tindakan Kelas,No. 4, Vol. 16, 2015.

Istiningrum dan Sukanti. Impelementasi Model Pembelajaran Kooperatif Tipe numbered Heads Together (NHT) Untuk Meningkatkan Aktifitas Belajar Akutansi Pada Siswa Kelas $x$ AK 2 SMK YKPP 2 Slema Tahun
Pembelajaran 2011/2012, Jurnal Pendidikan Akuntansi Indonesia,No. 2, Vol, 2012. hlm. 67.

Kariasa, W., I Made Ardana, I Wayan Sadra. Pengaruh Model Pembelajaran kooperatif Tipe STAD Dengan Pendekatan Pemecahan masalah Terhadap Kemampuan Berpikir Kritis Matemas Ditinjau Dari Penalaran Formal, Journal Program Pascasarjana Universitas Pendidikan Ganesha, Vol. 3, 2014.

Muharom, Tria. Pengaruh Pembelajaran Dengan Model Kooperatif Tipe student Teams Achievement Division (Stad) Kemampuan Penalaran Dan Komunikasi Matematik Peserta Didik Di SMK Negeri Manonja Kabupaten Tasikmalaya, Jurnal Pendidikan dan Keguruan, No. 1, Vol. 1, 2014.

Saputri, Lilis. Pengaruh Model Pembelajaran Kooperatif Tipe Jigsaw Terhadap Kemampuan Pemecahan Masalah Matematika Siswa SMP Swasta Swadaya Batang Serangan. Jurnal MathEducation Nusantara. p-ISSN: 2614-512X dan e-ISSN: 2614-5138, 2018.

Siswanto, Joko dan Siti Rechana. Pengaruh Model Pembelajaran kooperatif Tipe NHT (Numbered Heads Together) Menggunakan Peta Konsep Dan Peta Pikiran terhadap Penalaran Formal siswa, Jurnal JP2F,No. 2, Vol. 2, 2011.

Suprapto. Pengaruh Model Pembelajaran Kooperatif Tipe STAD Terhadap Peningkatan Kemampuan Representasi dan Pemecahan Masalah Matematis Siswa,Journal of Mathematics and Education, No. 3, Vol. 2, 2015.

Wakhyudin, H., Risty Juliyanti. Model Numbered Heads Together Terhadap 
Kemampuan Pemecahan Masalah Sisiwa Kelas IV , No. 2, Vol. 4, 2014.

Yulanda, N., Mukhni, Ahmad Fauzan.

Pengaruh Model Pembelajaran Kooperatif Tipe Student Teams Achievement Division
(STAD) Terhadap Pemahaman Konsep Matematika Siswa Kelas VII SMPN 3 Padang, Jurnal Pendidikan Matematika, No.1, vol. 3, 2014. 